\title{
Regulasi Emosi Pada Penari Tradisional Tari Klasik Gaya Surakarta Di Ukm Sentra Uin Raden Mas Said
}

\author{
Sandy Tyas Nurma Islami ${ }^{1,}$ Dhestina Religia Mujahid ${ }^{2}$ \\ Fakultas Ushuluddin dan Dakwah, UIN Raden Mas Said Surakarta \\ Jl.Pandawa, Dusun IV, Pucangan, Kec. Kartasura, Kabupaten Sukoharjo, Jawa Tengah \\ sandytyas1@gmail.com
}

\begin{abstract}
ABSTRAK
Ketidakmampuan mengelola emosi dalam kehidupan membuat seseorang tidak dapat menghadapi permasalahan yang penuh tekanan. Teknik regulasi emosi sangat penting dalam kehidupan. Salah satu cara untuk mengolah emosi dengan belajar tari klasik gaya Surakarta.Tujuan penelitian untuk mengetahui gambaran regulasi emosi penari tradisional tari klasik gaya Surakarta di UKM SENTRA UIN Raden Mas Said. Data penelitian adalah data kualitatif dengan pendekatan fenomenologi. Informan dalam penelitian ini diambil secara purprosive sampling sebanyak tiga penari putri dengan rentang usia 20-22 tahun. Sumber data berupa hasil dari wawancara semi terstruktur, observasi, dan dokumentasi. Analisis data menggunakan analisis deskripsi berupa pemaparan uraian dan diolah dengan menggunakan software atlas.ti. Hasil regulasi emosi di UKM SENTRA penari memiliki regulasi emosi yang baik berupa ketenangan diri, sabar, dapat beradaptasi dengan lingkungan baru, memiliki rasa empati yang baik, dan peka terhadap lingkungan. Informan menjadi lebih dapat memahami diri, percaya diri, memiliki kontrol diri yang baik, serta lebih bersemangat dalam menjalani hidup setelah tergabung dalam UKM SENTRA.
\end{abstract}

Kata kunci: Regulasi Emosi, Penari Tradisional, Triwira

\section{ABSTRACT}

The inability to manage emotions in life makes a person unable to deal with stressful problems. Emotion regulation techniques are very important in life. One way to process emotions is to learn classical dance in the Surakarta style. The purpose of the study was to describe the emotional regulation of traditional dancers in classical dance in the Surakarta style at UKM SENTRA UIN Raden Mas Said. The research data is qualitative data with a phenomenological approach. Informants in this study were taken by purprosive sampling as many as three female dancers with an age range of 20-22 years. Sources of data are the results of semi-structured interviews, observations, and documentation. Data analysis used descriptive analysis in the form of descriptions and processed using atlas.ti software. The results of emotional regulation in UKM SENTRA dancers have good emotional regulation in the form of calm, patient, able to adapt to new environments, have a good sense of empathy, and are sensitive to the environment. Informants become more self-aware, confident, have good selfcontrol, and are more enthusiastic in living life after joining UKM SENTRA.

Keywords: Emotion Regulation, Traditional Dancer, Triwira

\section{PENDAHULUAN}

Mengekspresikan kekecewaan menggunakan amarah bukan sesuatu yang keliru untuk dilakukan manusia. Sebaliknya, ketika seseorang memendam emosi serta amarah, maka dapat menyebabkan terjadinya gangguan kesehatan pada individu. Meskipun baik akan tetapi emosi serta amarah juga perlu dikendalikan. Normal bagi manusia tetapi jika emosi berkepanjangan dan parah akan mengakibatkan terjadi gangguan kesehatan mental (Sulaiman, Said, Habil, Rashid, \& Siddiq et, al 2014).

Penelitian yang berada di Eropa menyebutkan bahwa gangguan mental emosional berada pada posisi pertama dalam Disability Adjusted Life Years (DALYs) yaitu dengan angka 103,7/10.000 DALYs (Wittchen, 2011). Menurut hasil survei penduduk di Indonesia antar sensus terdapat 0,27 persen penduduk yang mengalami gangguan perilaku atau 
emosional, maka semakin bertambahnya usia semakin tinggi tingkat gangguan emosional (Lokadata, 2015). Individu yang menggebu emosinya cenderung akan bertindak kasar terhadap orang lain, seperti memukul atau menendang, berkata kasar dan berdampak kurang percaya diri, tidak mudah bersosialisasi, serta merasa dirinya tidak berguna, selain itu individu juga akan mudah merasakan frustrasi, tekanan darah tinggi dan tertekan, hal tersebut dapat berdampak negatif untuk individu (Ismail, 2017). Oleh karena itu, diperlukan regulasi emosi agar individu dapat memiliki managemen emosi yang baik dalam kehidupannya.

Regulasi emosi merupakan proses untuk mengelola emosi yang dinginkan atau diharapkan, serta mengekspresikan emosi agar dapat mengurangi stress dan kecemasan, berkaitan dengan marah, penolakan, serta rasa takut (Anwar, 2018). Ketika individu memiliki emosi yang stabil maka dapat mengendalikan emosinya dengan baik serta menyeimbangkan perasaan negatif dalam dirinya. Individu dapat mengolah emosi lebih objektif dan realistis dalam menganalisis permasalahannya dengan lebih baik. Sebaliknya ketika individu mempunyai emosi yang rendah maka akan timbul permasalahan yang tidak dapat di selesaikan oleh individu itu sendiri (Aleem, 2017). Hal penting dalam regulasi emosi yaitu mengubah emosi negatif ke emosi positif yang akhirnya dapat memberikan manfaat pada diri sendiri maupun orang lain (Zahrin, Mahmud, Kari, Omar, \& Sawai, 2020).

Menurut Sari dan Subandi (2015) cara untuk mengelola emosi yaitu dengan relaksasi yang bertujuan menurunkan tingkat ketegangan psikis maupun fisiologis akibat dari penyebab stres yang menekan serta menggantikannya dengan keadaaan relaks dan tenang. Relaksasi juga dapat mengurangi tingkat stres dengan menggunakan teknik relaksasi untuk meregulasi emosi serta fisik individu karena ketegangan, stres secara fisiologis, dan kecemasan. Teknik relaksasi dapat dilakukan dengan menggunakan seni tari (Arini, Oetopo, Setiawati, Khairudin, \& Nadapdap, 2008).

Seni tari juga menjadi salah satu media dalam Dance Movement Therapy (DMT) yaitu bentuk dari terapi yang menggabungkan segi fisik, emosional, dan kognitif, serta sosial dalam pengobatan. Dance Movement Therapy (DMT) atau terapi gerakan tari merupakan pendekatan holistik (menyeluruh) perihal gangguan kejiwaan, yang mana menggabungkan bermacam bagian dari medis, psikologis, sosial dan spiritual atau religiusitas (Levine \& Land, 2016). Dance Movement Therapy melibatkan klien dalam mengeksplorasi fisik maupun verbal dari pengalaman individu yang dihasilkan dari interaksi berbasis gerakan. Dimana nantinya berhubungan dengan pikiran dan tubuh individu, yang mana gerakan tubuh sebagai bentuk refleksi atas emosi yang keluar dari dalam, sehingga terdapat perubahan dalam bentuk perilaku gerakan dapat juga merefleksikan dan merubah psikis (Koch, Kunz, Lykou, \& Cruz, 2014).

Tari merupakan ungkapan dari ekspresi manusia, diubah oleh imajinasi, dibentuk melalui gerak menjadikan wujud gerak simbolis, menjadikan wujudan dari latihan-latihan, tari juga dipergunakan dalam mengembangkan kepekaan rasa, irama, dan gerak seorang penari (Aston, 2006). Penari merupakan seseorang atau sekelompok orang yang melakukan gerakan tarian serta memiliki maksud dan tujuan tertentu di dalamnya terdapat perencanaan pengorganisasian supaya keindahan tari terbentuk ke dalam satu penyajian yang utuh (Aston, 2006). Melalui perkembangannya penari dibedakan menjadi tiga yaitu penari tradisional, modern, dan kontemporer.

Menurut Muryanto (2019) tari tradisional atau klasik merupakan tari yang lahir dari keraton (Jawa) atau kaum bangsawan disebut tari tradisional klasik karena hanya berkembang 
dalam lingkungan keraton tertentu serta memiliki pakem tarian yang tidak dapat dirubah atau dikreasikan secara bentuk tarian maupun penyajiannya. Penari tradisional merupakan visualisasi dari bentuk tubuh seseorang atau sekelompok yang melakukan gerak tari ritmis yang bertujuan agar keindahan tari terbentuk kedalam satu penyajian atau karya seni yang utuh sesuai dengan pakem tarian dengan pembawaan tari klasik (Muryanto, 2019).

Menurut Dwiyasmono (2013) tari memiliki tiga konsep yaitu wiraga, wirasa, dan wirama, agar terciptanya karya tari yang indah maka perlu terpenuhinya semua konsep tari. Semua konsep dalam tari haruslah penari memiliki dan menyatukan dengan jiwa maupun tubuh seorang penari, sebab media dalam tari yang paling utama adalah dirinya sendiri, untuk menyampaikan pesan melalui gerak. Oleh karena itu tubuh penari mengalami secara langsung. Menurut Sriyadi (2013) bahwa konsep tari tidak bisa ditinggalkan dalam kepenarian tari klasik gaya Surakarta, dikarena hal itu sebagai pijakan untuk melaksanakan tari Jawa. Wiraga berperan penting dalam pelaksanaan gerak tari seperti sikap gerak, adeg, dan penggunaan serta pengaturan tenaga untuk bergerak pada suatu tarian. Wirama mencakup gending gerak tari dan irama gending maupun suasana, dipergunakan pada iringan tari. Wirasa meliputi rasa antara gerak dan iringan, dalam proses seorang penari harus melakukan pengulangan supaya yang akan dicapai dapat terpenuhi. Dalam menari penari tidak hanya dituntut hafal gerak saja melainkan dituntut greget. Untuk mencapai semua itu perlunya proses panjang yang harus dilalui oleh seorang penari.

Susanti (2011) menari pada dasarnya dapat mengurangi ketegangan, memberikan rasa relaks pada tubuh dan perasaan tenang yang di dapat oleh seorang penari, terkadang tubuh manusia sering gemetar karena, kurang percaya diri, tertekan, dan grogi. Susanti (2011) seorang penari apabila berhasil melalui dan menerapkan semua konsep tari dalam sebuah pertunjukan yang sudah melalui proses latihan secara sungguh-sungguh, maka dapat dikatakan seorang penari tersebut telah mencapai keberhasilan dalam pertunjukannya. Termasuk juga dalam hal proses regulasi emosi yang nantinya dapat diterapkan dalam kehidupan sehari-hari setiap individu atau penari, sehingga penari tersebut dapat memiliki regulasi emosi yang lebih baik.

Ketika semakin bertambahnya usia maka akan berpengaruh juga pada emosi yang ada dalam diri seseorang. Emosi yang dimaksud yaitu emosi positif lebih dominan dibanding dengan emosi negatif atau seimbang, serta dapat mengelola emosi yang ada. Pada kenyataannya dilapangan bahwa penari sudah masuk diusia dewasa masih belum dapat mengelola emosi dengan baik dan seimbang, yang mana penari memiliki regulasi emosi yang rendah. Regulasi yang rendah memiliki ciri-ciri sensitif, cemas, panik, harga diri rendah, gelisah, moody, kurang dapat mengontrol diri dan tidak memiliki kemampuan efektif dalam mengatasi stres (Gunthert, Cimbolic, Cohen, Lawrence, \& Armeli, 1999). Maka dari itu perlu adanya regulasi emosi, dimana media untuk meregulasi emosi salah satunya dengan menggunakan seni tari. Selama ini penelitian mengenai regulasi emosi pada penari tradisional masih sangat jarang dan penelitian tersebut dilakukan terlalu lampau maka peneliti ingin memperbarui penelitian yang sudah ada. Selain itu, saat ini tari klasik semakin banyak dilirik dan diminati oleh para pekerja seni karena mereka mulai memiliki kesadaran untuk melestarikan budaya tradisional seperti tari. Oleh karena itu, penelitian ini penting untuk dilakukan agar dapat memperoleh gambaran regulasi emosi yang dapat dilalukan dengan media tari klasik.

Hal tersebut kemudian menjadi menarik untuk diteliti, maka melalui penelitian ini, peneliti ingin mengkaji bagaimana gambaran regulasi emosi penari tradisional tari klasik gaya 
Surakarta di UKM SENTRA UIN Raden Mas Said. Adapun tujuan dari penelitian ini adalah untuk mengetahui gambaran regulasi emosi penari tradisional tari klasik gaya Surakarta di UKM SENTRA UIN Raden Mas Said.

\section{METODE}

Penelitian ini menggunakan jenis penelitian kualitatif dengan pendekatan fenomenologi karena peneliti ingin mengkaji bagaimana gambaran regulasi emosi pada penari tradisional tari klasik gaya Surakarta di UKM SENTRA UIN Raden Mas Said. Informan dalam penelitian ini dipilih secara proposive sampling dengan beberapa kriteria informan merupakan anggota UKM SENTRA dan mengikuti proses latihan tari klasik gaya Surakarta, serta informan memiliki regulasi emosi yang rendah. Regulasi yang rendah memiliki ciri-ciri sensitif, cemas, panik, harga diri rendah, gelisah, moody, kurang dapat mengontrol diri dan tidak memiliki kemampuan efektif dalam mengatasi stres (Gunthert, Cimbolic, Cohen, Lawrence, \& Armeli, 1999). Melalui pra penelitian, informan memiliki ciri-ciri regulasi yang rendah seperti mudah berubah mood (moodyan), mudah marah, panik, kurang percaya diri, minder, berpikir pendek, kurang tenang, ketakutan dalam diri, takut dinilai orang, egois, kurang beradaptasi dengan lingkungan sekitar, serta tertutup. Penelitian ini melibatkan tiga orang informan dan empat significant other. Menurut Sugiyono (2013) metode purposive sampling adalah teknik pengambilan sampel sumber data dengan menggunakan pertimbangan tertentu sehingga peneliti lebih mudah menjelajahi suatu objek atau situasi sosial yang diteliti.

Pengumpulan data penelitian menggunakan wawancara semi terstruktur sebagai data utama, agar dapat menggali berbagai aspek kehidupan informan secara utuh dan mendalam. Serta adanya observasi non partisipan, dan dokumentasi sebagai data pelengkap. Analisis data penelitian dimulai dengan mendiskripsikan pengalaman personal dengan fenomena yang sedang dipelajari, selanjutnya membuat daftar pernyataan penting, setelah itu mengambil pernyataan penting yang akan dikelompokkan menjadi unit atau tema dan menuliskan diskripsi tekstural mengenai apa yang dialami dari pengalaman informan serta mendiskripsikan deskripsi struktural mengenai bagaimana pengalaman tersebut terjadi atau berlangsung. Verifikasi dan kredibilitas penelitian dilakukan dengan member checking, triangulasi serta diskusi. Analisis data juga dibantu aplikasi atlas.ti versi 9 supaya memudahkan peneliti dalam memanggil kembali data primer penelitian. Penelitian ini dilakukan atas persetujuan dari semua informan dan informan dalam penelitian ini dirahasiakan data identitas dengan menginisalkan data diri informan.

\section{Informan Muna}

\section{HASIL}

Informan merupakan anak ketiga dari tiga bersaudara dengan memiliki dua orang kakak perempuan. Informan berusia 22 tahun, sekarang tinggal dikos dekat kampus. Hubungan informan dengan keluarga kurang begitu akrab selain dengan ayahnya, karena ayah menurut informan yang dapat mengerti informan ketika dirumah. Sekarang informan berpisah dengan keluarganya untuk melanjutkan pendidikan di Surakarta. Selama di Surakarta, informan memiliki sahabat dekat berinisial DL yang senantiasa menemani informan saat suka maupun duka dan kemana pun selalu bersama DL.

Informan mendalami dunia seni tari sejak melanjutkan pendidikan di kampus UIN Raden Mas Said tahun 2017. Informan di kampus bergabung dengan salah satu unit kegiatan mahasiswa yang bergerak dalam pengembangan minat dan bakat di bidang seni tari tradisi 
yang bernama UKM SENTRA. Informan mulai bergabung ketika adanya UKM Fire yang merupakan serangkaian kegiatan dari PBAK (Pengenalan Baru Akademik Kampus). Saat UKM Fire berlangsung, UKM SENTRA menyuguhkan penampilan menarinya yang sangat estetik dengan perpaduan tarian Nusantara, membuat informan berfikir ulang untuk mempelajari seni tari, dan memiliki keinginan supaya mampu mengontrol emosi maupun mengolahnya melalui wadah seni tari di UKM SENTRA agar bisa tersalurkan dengan baik serta memiliki kontrol emosi yang lebih baik, maka dari itu informan mendaftarkan diri bergabung dengan organisasai ini.

Selama bergabung dengan UKM SENTRA informan mendapatkan tarian Nusantara dari berbagai pulau, tetapi selama berproses di SENTRA dan berkuliah, informan juga mendapatkan berbagai kendala masalah yang datang kepada informan. Dimana dengan regulasi emosi informan yang rendah membuat informan kesulitan untuk menyelesaikan permasalahan-permasalahan yang ada. Informan yang kurang percaya diri, dan kurang tenang dalam bertindak serta kurang dapat mengontrol emosinya membuat informan merasa kesal dengan dirinya, hal itu mengakibatkan informan merasa tidak berguna dan menutup diri dari lingkungan sekitar. Sehingga membuat orang yang ada disekeliling informan juga ikut menanggung dampak dari emosi informan.

Hal tersebut akhirnya membuat informan kesal dengan dirinya mengapa informan tidak dapat mengontrol emosinya ketika emosi. Maka dari itu informan bercerita dengan pelatih tari di SENTRA dan disarankan mencoba mengolah emosi dengan ikut bergabung latihan tari klasik gaya Surakarta yang sangat bertolak belakang dengan basic awal informan. Informan memiliki basic tari lebih ke Jawa Timuran, Jaipong yang gagah, energik dan licah, sedangkan untuk tari klasik gaya Surakarta memiliki karakter yang lembut dan berwibawa. Hal tersebut membuat informan harus bisa cepat mengikuti setiap tahap latihan dari tari klasik gaya Surakarta, yang mana gerakan, musik yang sangat berbeda dengan tarian Nusantara dari daerah lainnya.

\section{Informan Amara}

Informan merupakan anak pertama dari dua bersaudara, dengan memiliki adik laki-laki berusia 16 tahun dan duduk di bangku sekolah menengah atas. Saat ini informan berusia 21 tahun dengan kegiatan keseharian menjadi mahasiswa. Informan memiliki hubungan yang kurang begitu harmonis dengan orang tuanya serta lebih tertutup atas apa yang dilaluinya kepada orang tuanya, dikarenakan informan dididik dari kecil untuk tidak mudah mengeluh, tidak mudah menyerah. Hal itu juga berdampak pada kehidupan informan yang tertutup sehingga apapun yang dirasakan informan baik marah, sedih yang berkaitan dengan emosi dalam diri tidak dapat diekspresikan keluar sehingga semua dipendam sampai menemukan tempat atau objek untuk pelampiasan.

Dampak dari semua itu menjadikan informan kurang percaya diri seperti sulit dalam menyampaikan atau menggungkapkan pendapatnya dan tidak percaya pada kemampuan diri informan, kontrol emosi yang kurang sehingga informan lebih mudah marah kepada orang yang ada disekitar, terlebih di luar rumah. Informan juga sering panik membuat sulit beradaptasi dan mengatur waktu. Ketika dihadapkan pada suatu permasalahan informan akan terbawa emosi tanpa difikir terlebih dahulu. Saat mengambil keputusan informan tidak memikirkan dampak dari keputusannya, sehingga terkadang informan dan lingkungan sekitarnya yang menanggung semua. 
Selepas adanya permasalahan tersebut berpengaruh pada aktivitas sehari-hari informan dan dalam melakukan sesuatu informan akan kurang tenang dalam bertindak, serta tidak ikhlas dalam melakukannya. Setiap ada permasalahan informan lebih suka membagikan cerita keluh-kesah ke sahabatnya yang berinisial NKN dari pada orang tuanya, karena menurut informan sahabatnyalah yang lebih dapat mengerti keadaannya. Informan saat ini masih menjadi salah satu mahasiswi di kampus UIN Raden Mas Said dan bergabung dengan organisasi yang bergerak dalam pengembangan minat dan bakat di bidang seni tari yaitu UKM Seni Tari Tradisi (SENTRA).

Selama bergabung di SENTRA informan menyadari bahwa emosi yang ada dalam dirinya perlu diolah karena informan merasa diusianya yang saat ini, informan masih memiliki pengolahan emosi yang rendah, maka dari itu informan bergabung dengan mengikuti latihan rutin tari klasik gaya Surakarta bersama Ge selaku assisten pelatih dan yang mendampingi latihan selama ini. Adapun faktor yang mendasari informan bergabung mengikuti latihan rutin tari klasik gaya Surakarta adalah informan ingin lebih mendalami seni tari gaya Surakarta, dan adanya keinginan untuk mengolah emosinya menjadi lebih baik lagi, karena informan sadar bahwa emosi yang ada dalam dirinya perlu adanya pengolahan.

\section{Informan Mawar}

Informan merupakan anak pertama dari dua bersaudara, dengan memiliki satu adik lakilaki. Informan di rumah tinggal bersama adik laki-lakinya, dikarenakan kesibukan orang tua yang bekerja membuat informan dan orang tuanya kurang adanya waktu luang sekedar untuk berkumpul. Kurangnya perhatian dari orang tua membuat informan merasa kekosongan dalam dirinya, hal tersebut membuat informan sering marah, mudah tersinggung, kurang percaya diri dan tertutup dengan lingkungan baru sehingga lebih sulit untuk cepat beradaptasi, serta dengan lingkungan yang baru informan lebih diam dan memperhatikan saja. Informan tidak berani menyampaikan pendapat di lingkungan yang baru sehingga membuat informan panik ketika dimintai untuk menyuarakan pendapat dan dihadapkan pada suatu keadaaan yang mengharuskan informan untuk berpendapat atau berreaksi.

Permasalahan yang sering informan alami selain terkait emosi yaitu terkait kuliah dan finasial. Gambaran ketika informan emosi yaitu marah dan meninggalkan tempat permasalahan, serta tidak peduli dengan keadaan disekitarnya. Tindakan yang ia lakukan setelah mengetahui permasalahan yang pertama adalah marah, berkata kasar, dan terkadang ketika sudah marah sekali barang yang informan bawa, akan dilempar atau jatuhkan dengan sengaja. Usia informan 20 tahun dan sekarang tengah menjalani proses belajar di bangku perkuliahan. Informan memiliki sahabat dekat berinisial RWA yang merupakan sahabat tempat informan bercerita mengenai permasalahan yang sedang dihadapi informan.

Tahun 2019 saat informan belum melaksanakan PBAK (Pengenalan Baru Akademik Kampus) informan sudah mencari-cari informasi terkait organisasi apa saja yang ada di kampus UIN Raden Mas Said, serta kegiatan apa saja yang akan di laluinya. Berawal dari sini informan terus mencari informasi terkait organisasi yang sesuai dengan diri informan, sebelum berlangsungnya PBAK dan berakhir dengan mengumpulkan beberapa organisasi yang menarik perhatian informan. Tepat ketika PBAK berlangsung terdapat sesi dimana adanya orasi dari setiap organisasi kampus baik UKM, UKK, Ormawa fakultas, informan tertarik dengan satu organisasi yaitu UKM SENTRA. Organisasi tersebut bergerak dalam pengembangan minat dan bakat di bidang seni tari, karena memang informan ingin mengembangkan potensi yang ada dalam diri informan. 
Alasan yang menjadi faktor informan mengikuti latihan tari klasik gaya Surakarta yaitu keinginan informan untuk bisa menari gaya Surakarta, dan ingin memperdalam lagi juga mengembangkan potensi diri khususnya tari klasik Surakarta, dan adanya keinginan mengolah emosi dengan media seni tari. Selain itu informan suka melihat seorang penari menari dengan rasa yang sampai pada hati informan, dan menurut informan menari bisa membuat informan tenang. Ketika informan mengalami suatu permasalahan dan membutuhkan objek untuk bisa mengalihkan serta mengolah emosinya, menurut informan ia akan menuangkannya pada latihan tari sehingga setelah berakhirnya proses tari, harapan informan dapat memiliki pengolahan emosi yang baik.

Informan sebelum bergabung latihan informan juga bercerita ke Ge mengenai informan yang sering marah, tersinggung, tidak percaya diri dan belum bisa mengontrol emosinya, dari cerita itu informan disarankan Ge yang melatih informan di SENTRA untuk melakukan relaksasi dengan mengikuti proses latihan tari klasik khususnya gaya Surakarta karena dalam tari banyak sekali yang bisa didapat terutama pada prosesnya.

\section{Ketika Proses Berlangsung}

Proses yang dilalui informan ada tiga yaitu wiraga, wirama, wirasa, yang mana wiraga terdapat dua proses besar meliputi olah tubuh dan olah gerak, wirama meliputi tempuk gending dengan gerak, wirasa yaitu olah rasa dengan metode meditasi. Proses dalam olah tubuh meliputi pemanasan, olah pernafasan, ketahanan tubuh dimana dimulai dari kepala sampai kaki, cium lutut, cium kaki, kayang, split dan gerakan pemanasan lainnya. Olah pernafasan terdapat sikap lilin dari posisi 90, 45, 35, 25 derajat dan kebalikan sampai 180 derajat, serta roll belakang, sedangkan untuk ketahanan tubuh melalui sit up, push up, lari. Biasanya dilakukan 2-4 set secara berulang dan bertahap (INF 1: Muna: W3:257-282).

Proses awal informan mengekspresikan emosi dalam dirinya dengan berteriak (INF 1: Muna: W3:227-240), dimana menurut informan:

“....cium lutut, cium lantai, kayang, splite, dan itu benar-benar sakit......terakhir 25 derajat yang menurutku sendiri paling susah karena selama proses ini harus mengatur nafas dan menguji kekuatan otot perut...perut akan ditekan" (INF 1: Muna: W3:264-282).

Proses panjang ini informan menjadi lebih sabar. Pada olah gerak diajarkan mengenai dasar gerak tari dan semua dilakukan secara berulang sampai benar sesuai dengan pakem tari, yang mana pada proses cancer dan mendek menurut informan sangat berat karena diulang sampai berkali-kali hingga kaki informan ngapal dan pegal (NF 1: Muna: W3:290-309). Setelah selesai maka informan diminta untuk presentasi gerakan baik di depan teman-teman maupun di tempat umum selain itu juga terdapat pengacakan tim penari sehingga informan juga harus cepat dalam beradaptasi. Mana kala proses tersebut membuat informan menjadi lebih sabar, percaya diri, dapat mengendalikan diri, tenang dalam bertindak, dan dapat beradaptasi (INF 1: Muna: W3: 310-320).

Proses yang kedua yaitu wirama atau tempuk gending yaitu pengsinkronisasian antara gending tari dengan gerak tari sehingga menjadi satu kesatuan dan selaras, yang mana tempo dari tari yang lembut dan lambat serta alunan gending yang merdu membuat informan memiliki ketenangan bertindak, berfikir cepat, bertindak tepat, fokus tujuan, ketenangan bertindak, berfikir jernih mana kala fokus saat proses sangat dibutuhkan apabila informan tidak fokus maka akan ketinggalan tempo tari dan harus mengulang semua dari awal hingga benar "....benar-benar ngepas antara musik, dan gerak, terkadang aku harus ngulang- 
ngulang sampai benar dan pegal tubuh ini ngulangnya." (INF1: Muna: W3:321-337) dari situ informan dapat mengolah emosinya.

Tahap terakhir wirasa atau olah rasa yang mana menggunakan meditasi dalam prosesnya. Proses meditasi meliputi, pemfokusan pikiran, bernafas secara perlahan dan teratur, duduk tenang lalu memejamkan mata serta mendengarkan satu intruksi yang diberikan, terkadang juga mendengarkan musik membuat informan tenang, relaks, mengenal diri sendiri, lebih peka, lebih berempati. Manakala faktor lingkungan juga berpengaruh pada proses meditasi, yang mana dilakukan pada malam hari dengan suasana sepi, angin yang berhembus sepoisepoi, dan tempat terbuka membuat proses ini lebih menyatu dengan diri informan. Proses ini yang didapat informan seperti tenang, relaks, mengenal diri sendiri, lebih peka, dan lebih berempati ( INF 1: Muna: W3:340-371).

Tahap setelah berakhirnya proses latihan yaitu pementasan, akan tetapi sebelum pementasan informan melakukan puasa sebagai wujud prihatin dengan maksud supaya Allah SWT memberikan kelancaran dan pertolongan kepada para penari. Puasa dilakukan supaya penari dapat lebih ikhlas, sabar dan dapat mengontrol dirinya, maupun emosinya. Semua proses panjang itu tidak akan menghianati hasil, jadi rasa informan ketika pentasan seperti tenang, enjoy, fellnya dapat, pesan yang ingin penari sampaikan pun juga sampai kepenonton ( INF 1: Muna: W72-382).

Berakhirnya proses maka informan mengaplikasian dari proses latihan rutin yang dilakukan informan dengan cara informan tetap berlatih dan menerapkan manfaat itu kediri informan secara konsisten, tetapi bukan hanya kediri informan saja, melainkan ke lingkungan sekitar informan juga, dengan informan dapat mengontrol emosinya itu cukup membantu ia agar tetap menjadi pribadi yang lebih baik dan tentunya seorang informan yang memiliki pengolahan emosi stabil tidak seperti dulu. Selain itu penerapan dari yang informan temui pada latihan tari di kehidupan sehari-hari seperti pola berfikir cerdas bertindak tepat tetapi tetap tanang dan memikirkan segala sesuatu yang akan terjadi dari tindakan informan, penerapan untuk selalu sabar dan tetap rendah hati, untuk mengenali kelamahan dan kelebihan diri informan, lebih mencintai diri informan, jadi ia juga harus tahu dimana titik terlemahnya dan bagaimana ia harus bangkit dan terus semangat menjalani hidup (INF 1: Muna: W3:383514).

\section{Informan Amara}

Informan Amara ketika proses latihan berlangsung emosi informan terkadang masih terbawa sampai tahap olah tubuh, setelah di tahap itu emosi informan mulai menurun, sehingga ia bisa fokus ke dalam latihan (INF 2: Amara: W3:383-514). Proses latihan yang harus informan Amara lalui ada beberapa tahapan yang terdiri dari olah tubuh, olah gerak, tempuk gending dan olah rasa, dimana dari keempat tahapan tersebut informan harus lalui sampai tuntas agar informan mendapatkan hasil yang terbaik (INF 2: Amara: W3:317-354). Pada tahap olah tubuh dan olah gerak menurut informan yang sangat membutuhkan banyak tenaga dan kesabaran (INF 2: Amara: W3:425-438).

“...Misal kaya pas olah tubuh dan gerak di awal gitu contohnya pas mendek, mendekkan harus sempurna itu kadang bisa terasa sakit kakinya kadang durasi mendek itu diulang sampai benar-benar sempurna, nah saat posisi itu aku harus fokus dan sabar maka lambat laun emosiku hilang dan digantikan dengan sabar sama nikmati proses" (INF 2: Amara: W3:317-326) 
Tahap olah tubuh informan melakukan pemasaan atau peregangan otot, sendi, pernafasan pada seluruh organ tubuh supaya berfungsi dengan baik, untuk membentuk kualitas gerak dari ujung kepala sampai ujung kaki tanpa terkecuali, serta ada olah pernafasan agar nafas penari lebih teratur, ketahanan biasanya dengan lari, dasar tari dilakukan berjangka seperti contoh mendek lima menit hingga sepuluh menit dan berulang, jika penari tidak melakukan olah tubuh akan berakibat fatal seperti cidera serta tidak maksimalnya dalam proses latihan setelah selesai tahap olah tubuh (INF 2: Amara: W3:326-354).

Proses tahap kedua yaitu olah gerak dimana sebelum proses tahap ini, informan diberikan arahan gerakan dan filosofi tarian supaya memahami karakter tari yang akan dibawakan. Setelah diberikan arahan dan contoh gerakan informan diminta memperagakannya sesuai dengan karakter tariannya, biasanya diberikan bertahap untuk gerakannya sehingga informan bisa mengikutinya, apabila dari materi gerakan yang diberikan belum sempurna informan dalam memperagakan maka akan diminta untuk mengulangi sampai benar gerakan tersebut (INF 2: Amara: W3:359-385). Gerakan yang sangat lambat dan lembut membuat informan sedikit kesulitan dalam memperagakannya dan mengharuskan informan untuk tetap sabar dan konsisten serta informan juga harus mengekspresikannya dengan tenang (INF 2: Amara: W3:404-438). Setelah memperagakan informan diminta mempresentasikan di depan umum secara individu dan secara acak untuk kelompok, supaya informan dapat memiliki rasa percaya diri yang lebih dan dapat cepat beradaptasi dengan lingkungan maupun orang lain.

Tahap selanjutnya wirama atau tempuk gending dimana gerak dan musik dipertemukan, maka tahap ini informan sudah harus memulai latihan kepekaan dengan gending-gending tari, yang mana jatuhnya gerak harus sesuai dengan jatuhnya ketukan gending, dan tidak diperbolehkan mendahului atau terlambat. Informan pada tahap ini fokus latihan dan mencoba untuk tetap berkonsentrasi agar ia tidak ketinggalan tempo musik dan gerakan tari serta ia berusaha untuk mengendalikan dirinya (INF 2: Amara: W3:475-503). Tahap ini yang dirasakan informan.

“....Kalau yang aku rasakan saat tahap tempuk gending, aku merasa lebih tenang karena musik gamelan jawa yang merdu dapat membuat suasana hatiku lebih rileks saat mendengarnya, terus ketika suasana hatiku ini berubah menjadi tenang, membuatku menjadi pribadi yang tidak terburu-buru, dan setiap tindakanku aku

fikirkan dulu, jadi tidak asal-asalan dalam menentukan pilihan serta tindakan" (INF

2: Amara: W3:481-490)

Tahap yang terakhir dari proses latihan yaitu olah rasa dimana pada tahap ini informan diajak untuk meditasi, proses ini biasanya dilakukan dua sampai tiga kali dalam satu bulan apabila terjadi kendala waktu biasanya dilakukan satu sampai dua kali dalam satu bulan. Selama informan mengikuti latihan rutin tari klasik gaya Surakarta olah rasa ini dilakukan dua kali dalam satu bulan, dengan bertempat di alam terbuka saat malam hari, selain itu juga ada faktor pendukung keberhasilan olah rasa.Proses meditasi biasanya tergantung dari Ge dan yang mendampingi latihan, untuk yang sudah dilalui informan selama proses itu seperti ia diminta untuk menenangkan diri terlebih dahulu, selanjutnya fokus pada satu titik suara, dan merelakskan tubuh (INF 2: Amara: W3: 506-526). Proses ini informan merasa lebih tenang, lebih mengenal dirinya, sabar dan lebih berempati dengan sekitar, serta relaks sehingga dapat mengendalikan emosinya menjadi lebih baik lagi (INF 2: Amara: W3: 527-544).

Pengaplikasian setelah berakhirnya proses latihan rutin tari klasik gaya Surakarta, informan mengaplikasikannya ke dalam dirinya terlebih dahulu sebelum ke lingkungan sekitar. Informan mengaplikasikan dengan tetap berlatih tari secara konsisten, ia juga 
mengaplikasikan meditasi disetiap dua hari sekali ketika di rumah. Informan dengan lingkungan sekitar lebih empati dan dapat beradaptasi, melalui proses yang dilaluinya dan perubahan yang terjadi pada informan terkait regulasi emosi informan, ia sekarang lebih bahagia dan bersemangat menjalani hidup. Ia juga mengaplikasikan dengan cara tidak mudah marah, sabar, tenang dan difikirkan kembali sebelum ia bertindak atau mengambil keputusan (INF 2: Amara: W3: 601-621).

\section{Informan Mawar}

Proses awal yang dilaluli informan Mawar yaitu olah tubuh dan olah gerak dimana dalam proses olah tubuh informan pemasaan atau peregangan otot, sendi, pernafasan pada seluruh organ tubuh supaya berfungsi dengan baik, untuk membentuk kualitas gerak. Pada proses tahap ini berlangsung informan mengeluarkan emosi dalam diri, supaya informan dapat fokus ke tahap selanjutnya dan emosi yang dibawa informan bisa terkurangi dengan cara meluapkannya di proses awal meskipun itu semua tidak serta merta langsung menghilangkan emosi informan sepenuhnya akan tetapi emosi yang sebelumnya memuncak akan mereda sehingga di tahapan selanjutnya emosi tersebut lama kelamaan akan menghilang dan tergantikannya dengan rasa tenang dalam diri informan (INF 3: Mawar: W3: 243-298). Salah satu proses awal yang dirasakan informan

“... Aku biasanya diminta untuk peregangan otot lanjutan seperti cium lutut, cium lantai...terus ada split sama kayang dan itu sungguh-sungguh sakit sekali mbak, biasanya aku njerit itu, seklaian aku keluarkan emosi yang masih terbawa sebelumnya, biar plong juga" (INF 3: Mawar: W3: 260-268).

Tahap setelah olah tubuh yang dilalui informan yaitu olah gerak dimana informan dituntun untuk lebih bisa mendalami setiap detail-detail gerakan yang ada dalam tari klasik gaya Surakarta, dengan gerakan yang lembut, halus ia harus dapat menyesuaikannya, informan juga menceritakan bahwa proses tahap ini ketika melakukan kesalah gerak, maka ia akan diminta mengulangi gerakan sampai benar sesuai dengan detail gerakan, sehingga proses ini membuat informan menjadi lebih sabar (INF 3: Mawar: W3: 299-321).

Selama proses latihan berlangsung informan juga diminta untuk mempresentasikan gerakan yang sudah di pelajari sebelumnya untuk dapat melanjutkan ketahap selanjutnya, hal ini harapannya selain informan hafal materi, ini merupakan salah satu cara melatih rasa percaya diri para penari serta cara beradaptasi dengan hal baru. Informan saat presentasi ia yang dulunya tidak percaya diri mau tidak mau harus memberanikan diri untuk presentasi mandiri individu di depan umum, sehingga lama kelamaan hal itu membuat informan menjadi percaya diri dengan kemampuan yang ia punya, selain itu informan juga harus dapat mengendalikan dirinya, karena gerakan yang dibawakan lebih lambat dan halus, maka ia juga harus menyesuaikan diri sesuai dengan karakter serta filosofi tari itu (INF 3: Mawar: W3: 322-333).

Tahap tempuk gending dimana proses tahap ini menurut informan yang sangat melelahkan dibandingkan tahapan proses sebelumnya karena informan harus tepat dan pas, apabila tidak maka informan akan diminta untuk mengulang hingga benar, terkadang satu kali latihan harusnya mendapat delapan hingga sepuluh gerakan untuk yang lain, karena terkadang informan tidak sempurna dalam tempo maka informan hanya mampu empat sampai enam saja, akan tetapi informan akan mengejar ketertinggalannya dengan berlatih di luar jam latihan rutin dengan merekam dan dikirim ke Ge untuk dikoreksi detail gerak dan temponya (INF 3: Mawar: W3: 322-333). 
Proses tempuk gending yang dirasakan informan yaitu deg-degan, karena harus menyingkronkan tempo gending dengan gerak, serta mengharuskan informan untuk benarbenar fokus dan konsentrasi, sebab jika tidak berkonsentrasi maka informan akan ketinggalan tempo tari, jadi ketika ditahap ini informan sudah tidak memikirkan hal lain dan fokus ke latihan saja. Hal yang didapat informan pada proses ini seperti informan mendapatkan fokus tujuannya kembali, diajarkan untuk bisa mengendalikan diri informan, karena harus menyingkronkan antara gerakan tari dengan gending tari, sehingga informan harus mampu mengendalikan dirinya, serta harus tepat dalam bertindak sebab di sini ia juga dilatih secara tidak langsung untuk bertindak tenang dan berhati-hati (INF 3: Mawar: W3: 357-412).

Proses selanjutnya yang harus informan lalui yaitu olah rasa dimana pada tahap ini informan diajak untuk meditasi. Proses meditasi biasanya tergantung dari Ge dan yang mendampingi latihan. Proses yang sudah dilalui informan seperti, ia diminta untuk menenangkan diri terlebih dahulu, memejamkan mata selanjutnya fokus pada satu titik suara instruksi sugesti, dan merelakskan tubuh serta menyatukan diri dengan alam sekitar. Proses ini informan merasa lebih tenang, lebih mengenal dirinya, sabar dan lebih empati dengan sekitar, serta relaks sehingga dapat mengendalikan emosinya menjadi lebih baik lagi. Selain itu adanya faktor pendukung suasana, kondisi lingkungan, dan media musik ataupun lilin (INF 3: Mawar: W3: 425-459). Akhir adri proses informan juga diminta untuk berpuasa dua hari sebelum pementasan, tepatnya h-1 dan hari $\mathrm{H}$, apabila penari tidak mampu maka dapat melalukan puasa selama satu hari. Supaya informan menjadi lebih tenang dan sabar selain dengan proses panjang informan juga dibantu dengan nilai-nilai religi yang ditanamkan dalam tari (INF 3: Mawar: W3: 334-342).

Informan setelah berakhirnya proses latihan rutin tari klasik gaya Surakarta terdapat perubahan dalam hal regulasi emosi yang baik seperti lebih plong, tenang, relaks, sabar, dan tidak panik, informan juga lebih percaya diri, memiliki rasa empati yang tinggi dibandingkan sebelumnya yang tidak peduli dengan sekitar, lebih difikirkan dahulu sebelum bertindak, dan sekarang ia sudah dapat beradaptasi dengan hal baru, jika marah informan dapat meredam dan mengontrolnya berbeda dari yang sebelumnya. Setelah proses berakhir informan juga menuturkan bahwa emosinya lebih terkontrol dan menjalani hidup lebih ringan, serta bersemangat dari sebelum-sebelumnya karena dulu ketika informan sudah ada beban diawal yang membuat mood maupun perasaannya hancur maka dalam kehidupannya terasa berat dan tidak bersemangat (INF 3: Mawar: W3: 610-720).

Pengaplikasian dari proses yang sudah informan lalui ke dalam dirinya yaitu dengan tidak bertindak gegabah, lebih selektif lagi dalam menerima informasi, sabar dan harus tenang ketika dihadapkan pada suatu permasalahan, ketika sedih atau stress informan menerapkan meditasi mandiri dirumah atau di tempat yang mendukung untuk ia melakukan meditasi, agar proses yang sudah dilaluinya saat latihan rutin tidak sia-sia percuma tanpa ia terapkan didirinya. Sedangkan untuk emosi informan ketika menghadapi suatu permasalahan setelah menerapkan proses latihan rutin tari ia lebih tenang, lebih sabar, ia akan memfikir terlebih dulu dan tidak terburu-buru dalam mengambil keputusan, dan lebih berhati-hati dalam bertindak apakah yang ia ambil memiliki resiko yang besar untuk orang-orang disekitarnya serta dampak itu berjangka panjang atau tidak (INF 3: Mawar: W3: 723-740). 


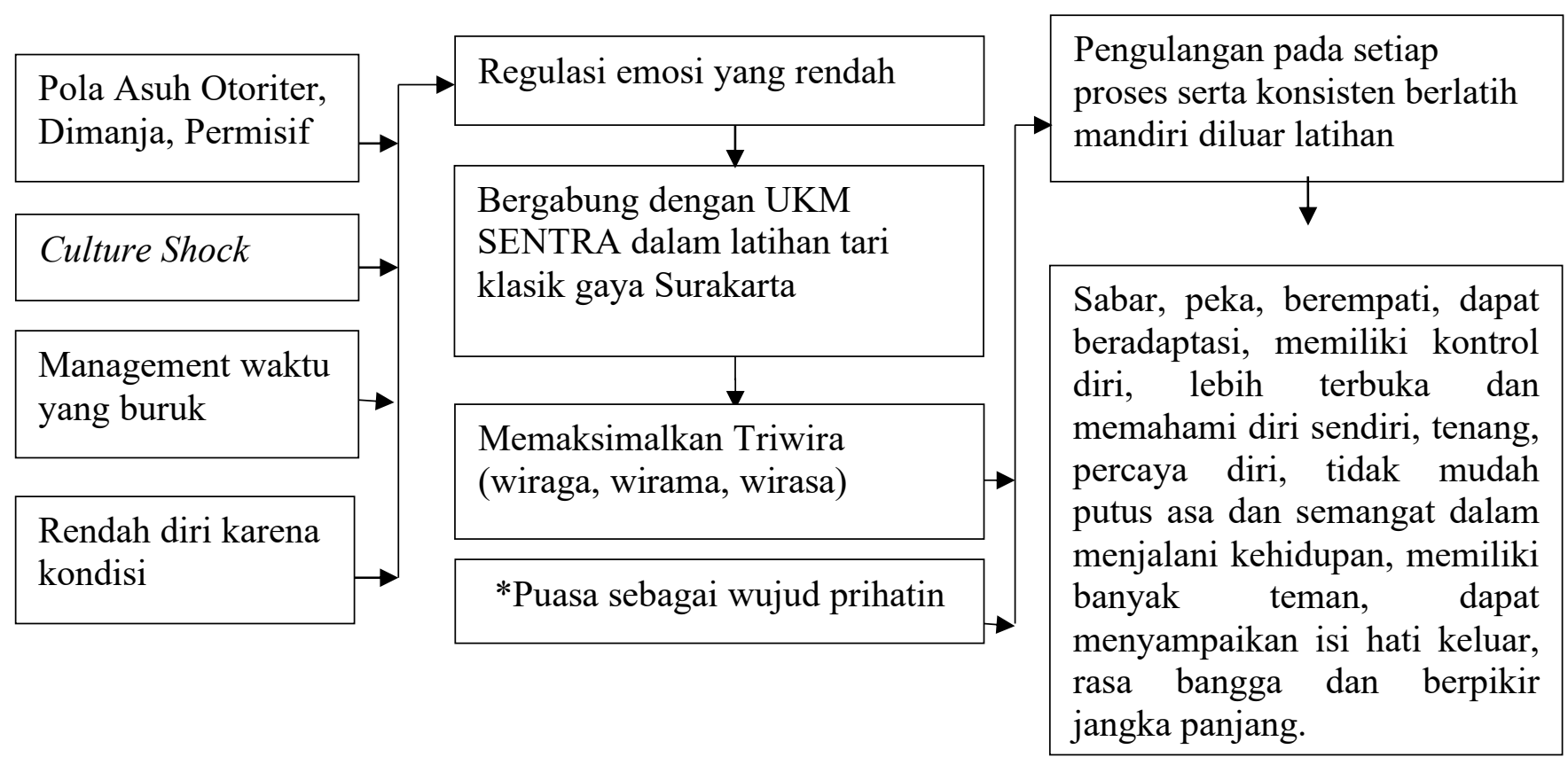

\section{Keterangan:}

* Dilakukan oleh Muna \& Mawar

*Amara tidak melakukan puasa dikarenakan tidak melaksanakan pementasan

\section{Gambar 1.Matrik proses regulasi emosi ketiga informan}

\section{DISKUSI}

Regulasi emosi adalah proses yang memiliki tujuan untuk mengatur serta mengelola emosi yang diinginkan serta bagaimana mengalami dan mengekspresikan emosi agar dapat mengurangi stres pada individu (Anwar, 2018). Hal ini sejalan dengan ketiga informan dalam mengolah emosi menggunakan media seni tari khususnya tari klasik gaya Surakarta, yang mana dalam proses tari semua informan dapat mengekspresikan emosi yang ada dalam dirinya sehingga dapat mengurangi ketengangan yang ada, serta dapat mengatur maupun mengelola emosi menjadi lebih baik dari sebelumnya.

Regulasi emosi ketiga informan sebelum mengikuti latihan rutin tari klasik gaya Surakarta yang rendah seperti mood yang sering berubah-ubah (moodyan), panik, kurang tenang dalam bertindak, kurang dapat beradaptasi dengan lingkungan yang baru, kurang percaya diri dan mudah marah (sensitif), merasa dirinya tidak berguna, stress (tertekan) dan kurangnya kontrol diri. Regulasi yang rendah dicirikan dengan memiliki kepribadian neuroticism memiliki ciri-ciri sensitif, cemas, panik, harga diri rendah, gelisah, moody, kurang dapat mengontrol diri dan tidak memiliki kemampuan efektif dalam mengatasi stres akan menunjukkan regulasi emosi yang rendah (Gunthert, Cimbolic, Cohen, Lawrence, \& Armeli, 1999). Dimana ciri-ciri tersebut lebih dari 4 terdapat pada diri informan, yang mana menandakan ketiga informan belum memiliki regulasi yang baik. 
Gross (2014) faktor-faktor regulasi emosi ada 5 yaitu: usia dan jenis kelamin, religiusitas, kepribadian, pola asuh, budaya. Adapun dari data lapangan bahwasannya yang melatarbelakangi informan memiliki regulasi yang rendah yaitu faktor pola asuh, yang mana pada ketiga informan bahwasannya pola asuh dan kondisi keharmonisan keluarga kurang, seperti informan Amara pola asuh orang tua yang otoriter, informan Muna pola asuh yang sering dimanja dan informan Mawar pola asuh orang tua yang tidak terlibat. Brown (2011) berpendapat bahwa ketidakmampuan individu dalam hal regulasi emosi ketika peristiwa dalam kehidupan penuh tekanan berakibat pada tertundanya perkembangan perilaku sosial serta fungsi individu dalam suatu keluarga maupun masyarakat. Selain itu faktor budaya juga melatarbelakangi regulasi emosi seperti pada informan Muna yang mana terdapat perbedaan kultur budaya daerah. Menurut Anggraini dan Desiningrum (2018) dalam penelitiannya bahwa beradaptasi dengan lingkungan yang jauh berbeda kultur budaya dengan sebelumnya akan semakin sulit dalam penyesuaian diri, disini kemampuan regulasi emosi menjadi kekuatan untuk dapat diterima secara sosial di lingkungan baru.

Informan memutuskan untuk bergabung dengan latihan tari klasik gaya Surakarta, yang mana faktor budaya juga memiliki peran besar dalam suatu proses regulasi emosi. Menurut Pamardi, Haryono, Soedarsono, dan Kusmayati (2014) tari klasik gaya Surakarta memiliki gerakan yang lembut dan berwibawa dibandingkan dengan tarian tradisional lainnya. Sehingga dalam hal konsep tari akan dapat mengolah emosi penari lebih baik. Dalam proses latihan tari klasik gaya Surakarta terdapat konsep tari yang harus terpenuhi yang biasa disebut tri wira. Dwiyasmono (2013) konsep seni tari tradisi gaya Surakarta yang biasa di sebut dengan tri wira adalah wiraga, wirasa, dan wirama. Ketika proses wiraga yaitu gerak, dimana proses wiraga dalam latihan terdapat dua kesatuan yaitu olah tubuh dan olah gerak, yang mana melalui proses tersebut membuat ketiga informan belajar arti kesabaran, keikhlasan, rasa percaya diri, kontrol diri serta dituntut untuk dapat dengan cepat beradaptasi dengan lingkungan sekitar. Proses yang dilalui seperti pemanasan, olah pernafasan, ketahanan, dan olah gerak, dari proses tersebut digunakan ketiga informan untuk mengeluarkan dan mengekspresikan segala emosi yang ada dalam diri informan sehingga bisa tersalurkan dan terolah dengan baik, serta adanya pengulangan dari setiap proses yang ada. Menurut Filar dan Mierzwa (2016) bahwa latihan tari atau dance therapy dapat membantu meningkatkan ketrampilan keseimbangan.

Sejalan dengan hasil lapangan untuk proses wirama dapat mengajarkan ketenangan, bertindak tepat, tenang, serta dapat berfikir panjang dan berhati-hati dalam mengambil suatu keputusan. Manakalanya proses wirama untuk mengolah emosi yaitu dengan memadukan musik dengan gerak yang sudah didapat sebelumnya supaya menjadi suatu kesatuan, dalam wirama ini tempo gending dan gending gamelan Jawa merdu dapat mempengaruhi pengolahan emosi ketiga informan serta pengulangan proses untuk melatih ketepatan informan. Sejalan dengan hal tersebut menurut Indrawati (2018) dalam penelitiannya bahwa dengan mendengarkan musik relaksasi dapat berpengaruh pada penuruan kecemasan. Menurut Haryadi dan Fardan (2015) dalam penelitian yang sudah dilakukannya bahwa terdapat perubahan yang signifikan terhadap regulasi emosi setelah diperdengarkan musik klasik.

Wirasa dari data lapangan didapat ketenangan, relaks, sabar, empati, dapat memahami diri setiap informan. Sejalan dengan hasil yang didapat pada proses olah rasa menggunakan media meditasi Contoh proses dalam meditasi yaitu informan diminta untuk menenangkan dirinya, mengatur nafas secara teratur, dibantu juga dengan gending gamelan Jawa yang 
berintonasi rendah serta intruksi sugesti yang diberikan saat proses berlangsung. Didukung oleh suasana lingkungan yang sepi dan hening. Menurut Sarwono (2013) meditasi adalah media untuk pemusatan fikiran pada satu titik secara terus menerus. Selain itu menurut Tristaningrat (2020) dalam penelitiannya bahwa meditasi memiliki banyak manfaat untuk kehidupan, sebab melalui meditasi dapat memperoleh kedamaian, sehat, dan bahagia lahir maupun batin, serta meditasi dapat meningkatkan resiliensi dan kesejahteraan individu. (Gross, 2014) mengatakan bahwa adanya lima aspek untuk meregulasi emosi yaitu: Situation selection, situation modification, attentional deployment, cognitive chage, response modulation, dimana dari semua tahapan dalam regulasi emosi dapat terpenuihi semua oleh para informan.

Peran seni tari sebagai media Dance Movement Therapy (DMT) juga terbukti dapat meregulasi emosi penari sehingga penari dapat memiliki regulasi emosi yang baik setelah mengikuti latihan. DMT atau terapi gerakan tari merupakan pendekatan holistik (menyeluruh) perihal gangguan kejiwaan, yang mana menggabungkan bermacam bagian dari medis, psikologis, sosial dan spiritual atau religiusitas (Levine \& Land, 2016). Sedangkan untuk proses DMT terdapat 4 tahapan menurut (Swasti, 2021) proses Dance Movement Therapy (DMT) terdapat 4 bagian yaitu: Preparation, Incubation, Ilumination, dan Evaluation. Berdasarkan data penelitian yang di dapat bahwasnnya proses DMT dapat dilalui para informan selama mengikuti proses latihan selama 3 bulan dengan total 180 jam pertemuan dilaksanakan dengan baik dan konsisten, serta adanya kesamaan dari proses DMT dengan proses latihan tari yang diterapkan di UKM SENTRA sehingga para informan dapat menyelesaikannya dan mendapatkan hasil yang maksimal, selain itu para informan juga menerapkan latihan mandiri di rumah ataupun saat waktu luang untuk menjaga konsistensi latihan. Sejalan dengan hal tersebut menurut Jiang, Nanjappan, Bhomer, dan Liang (2021) bahwasannya interaksi berbasis gerak dapat meningkatkan emosi positif.

\section{KESIMPULAN}

Berdasarkan penelitian dan pembahasan skripsi yang berjudul "Regulasi Emosi pada Penari Tradisional Tari Klasik Gaya Surakarta di UKM SENTRA UIN Raden Mas Said" yaitu tari dapat membantu mengolah emosi dengan memaksimalkan triwira yaitu wiraga (olah tubuh dan olah gerak), wirama (tempuk gending), wirasa (meditasi) dan puasa. Didapat hasil berupa ketenangan diri, sabar, dapat beradaptasi dengan lingkungan baru, memiliki rasa empati yang baik, peka terhadap lingkungan, rasa percaya diri, dan dapat memahami diri sendiri, memiliki kontrol diri yang baik, serta lebih bersemangat dalam menjalani hidup.

\section{DAFTAR PUSTAKA}

Ahmad Hatim Sulaiman, Mas Ayu Said, Mohd Hussain Habil, Rusdi Rashid, Amer Siddiq, Ng Chong Guan, Marhani Midin, Nik Ruzyanei Nik Jaafar, Hatta Sidi, S. Das. (2014). The risk and associated factors of methamphetamine psychosis in methamphetaminedependent patients in Malaysia. ELSEIVER, Vol 55, Ta, S89-S94. https://doi.org/https://doi.org/10.1016/j.comppsych.2013.01.003

Anwar, K. (2018). Hubungan antara Regulasi Emosi dengan Stress Akademik pada Mahasiswa Baru. In UINSUKA. UIN Sunan Kalijaga, Yogyakarta.

Aston, S. (2006). Apresiasi seni(seni tari dan seni musik). Yudistira.

Brown, C. L. (2011). The Effects of Parental Conflict and Close Friendships on Emotion 
Regulation in Adolescence. University of Virginia Press.

Data, L. (2015). Presentase penduduk yang mengalami gangguan perilaku/emosional,2015. Badan Pusat Statistik.

Dwiyasmono. (2013). Analisis estetis tari driasmara. Greget, 12(2), 186-195.

Gross, J. J. (2014). Handbook of Emotion Regulation.

Gunthert, Kathleen Cimbolic,Cohen, Lawrence H.,Armeli, S. (1999). The Role of Neuroticism in Daily Stress and Coping. American Psychological Association, Vol 77(5), 1087-1100.

H U Wittchen, F Jacobi, J Rehm, A Gustavsson, M Svensson, B Jönsson, J Olesen, C Allgulander, J Alonso, C Faravelli, L Fratiglioni, P Jennum, R Lieb, A Maercker, J van Os, M Preisig, L Salvador-Carulla, R Simon, H.-C. S. (n.d.). The size and burden of mental disorders and other disorders of the brain in Europe 2010. Eur Neuropsychopharmacol, 9, 655-679. https://doi.org/10.1016/j.euroneuro.2011.07.018.

Halodoc. (2018). Emosi Meledak-Ledak, Tanda Mental yang Tidak Stabil. Halodoc.

Indrawati, R. (2018). Efektivitas Mendengarkan Musik Relaksasi Terhadap Penurunan Tingkat Kecemasan Akademik Siswa SMA Negeri 3 Gowa dan SMA 1 Lappariaja sebelum Menghadapi Ujian. Eprint UMN.

Ismail, I. H. Bin. (2017). Stres Dan Kesihatan. UTM.

Jiang, M., Nanjappan, V., Ten Bhömer, M., \& Liang, H. N. (2021). On the use of movementbased interaction with smart textiles for emotion regulation. Sensors (Switzerland), 21(3), 1-20. https://doi.org/10.3390/s21030990

K.Filar-Mierzwa, M. D. (2016). The Effect of Dance Therapy on the Balance of Women Over 60 Years of Age: The Influence of Dance Therapy for The Elderly. Woman and Ageing.

Koch, S., Kunz, T., Lykou, S., \& Cruz, R. (2014). Effects of dance movement therapy and dance on health-related psychological outcomes: A meta-analysis. Arts in Psychotherapy, 41(1), 46-64. https://doi.org/10.1016/j.aip.2013.10.004

Laili Nur Oktavin Anggraini, D. R. D. (2018). Hubungan Antara Regulasi Emosi Dengan Intensi Agresivitas Verbal Instrumental Pada Suku Batak Di Ikatan Mahasiswa Sumatera Utara Universitas Diponegoro. Jurnal Empati, Volume 7 (, 270-278.

Levine, B., \& Land, H. M. (2016). A Meta-Synthesis of Qualitative Findings about Dance/Movement Therapy for Individuals with Trauma. Qualitative Health Research, 26(3), 330-344. https://doi.org/10.1177/1049732315589920

Muryanto, S. P. (2019). Mengenal Seni Tari Indonesia (Susilo (ed.)). ALPRIN.

Pamardi, S., Haryono, T., Soedarsono, R. ., \& Kusmayati, A. H. (2014). Karakter dalam Tari Gaya Surakarta. Gelar : Jurnal Seni Budaya, 12(2), 220-235.

Rifa'i, T. dan M. I. (2019). Efikasi diri dan regulasi emosi dalam mengatasi Prokrastinasi Akademik. CV. Sindunata.

Sari, A. D. K., \& Subandi. (2015). Pelatihan teknik relaksasi untuk menurunkan kecemasan pada primary caregiver penderita kanker payudara. Gadjah Mada Journal of Professional Psychology, 1(3), 173-192.

Sarwono, S. (2013). Psikologi Remaja. Raja Grafindo.

Sheema Aleem. (2017). Emotional Stability among College Youth. Journal of the Indian Academy of Applied Psychology, 31(April), 100-102.

Sri Hermawati Dwi Arini, Ataswarin Oetopo, Rahmida Setiawati, Deden Khairudin, M. R. N. (2008). Seni Budaya Jilid 2. Direktorat Oembinaan Sekolah Menegah Kejuruan.

Sriyadi. (2013). Tari Tradisi Gaya Surakarta. Greget, 12 No 2. 
Sugeng Haryadi, N. N. F. (2015). Pengaruh Musik Klasik Terhadap Regulasi Emosi Tunadaksa di Ypac Surakarta. Talenta, Volume $1 \mathrm{~N}$.

Sugiyono. (2013). metode Penelitian Pendidikan (Pendekatan Kuantitatif, Kualitatif, dan $R \& D)$.

Susanti, T. F. (2011). Pengendalian Emosi. Eprint Ums.

Swasti, I. K. (2021). Proses dalam Dance and Movement Therapy. www.youtube.com.

Syaidatun Nazirah Abu Zahrin, Mohd Izwan Mahmud, Dharatun Nissa Puad Mohd Kari, Halizah Omar, Rezki Perdani Sawai, J. P. S. (2020). Regulasi Emosi Dalam Penulisan Dan Penerbitan Jurnal Dalam Kalangan Ahli Akademik. AJTLHE, 12(1985-5826), 4253.

Tristaningrat, M. A. N. (2020). Meditasi Mindfulness Dalam Menjaga Emotional Stability. Haridracarya, Vol. 1, No. 